\title{
PERSEPSI MASYARAKAT TERHADAP IMPLEMENTASI KEBIJAKAN ZONASI SEKOLAH DALAM PENERIMAAN PESERTA DIDIK BARU (PPDB) TINGKAT SMA TAHUN AJARAN 2017/2018 DI KOTA SAMARINDA
}

\section{PUBLIC PERCEPTION REGARDING POLICY IMPLEMENTATION ON SCHOOL ZONING POLICY IN THE ACCEPTANCE OF HIGH SCHOOL NEW STUDENTS YEAR 2017/2018 IN SAMARINDA}

\author{
Ratih Fenty A. Bintoro \\ Badan Penelitian dan Pengembangan Provinsi Kalimantan Timur \\ Jalan M.T. Haryono Rawa Indah Samarinda 75124 \\ Email : fentybintoro@gmail.com
}

Diterima : 27 Agustus 2018; Direvisi : 12 September 2018; Disetujui : 17 September 2018

\begin{abstract}
ABSTRAK
UU Nomor 20 Tahun 2003 tentang Sisdiknas menyebutkan bahwa setiap warga negara mempunyai hak yang sama untuk memperoleh pendidikan yang bermutu. Namun fenomena yang terjadi saat ini terdapat kesenjangan yang cukup kasat mata karena maraknya sekolah negeri berlabel unggul yang digagas pemerintah di hampir setiap daerah yang tentu membuka jurang kesenjangan yang begitu lebar dengan sekolah lain yang berstatus tidak unggul. Sekolah unggulan terkesan hanya bisa dinikmati anak-anak dengan kemampuan akademik serta finansial tertentu. Orang tua murid pun berlomba untuk menyekolahkan anaknya di sekolah unggulan. Sehingga dampaknya ada sekolah yang banyak muridnya dan ada sekolah yang kekurangan siswa. Tentu saja ketidakmerataan ini akan menimbulkan ekses yang tidak baik pada dunia pendidikan nasional.

Menyikapi hal tersebut, pemerintah melalui Kementerian Pendidikan dan Kebudayaan menetapkan Permendikbud Nomor 17 Tahun 2017 tentang Penerimaan Peserta Didik Baru pada Taman Kanak Kanak, Sekolah Dasar, Sekolah Menengah Pertama, Sekolah Menengah Atas, Sekolah Menengah Kejuruan atau bentuk Lain Yang Sederajat. Dalam Permendikbud tersebut ditetapkan pemberlakuan sistem zonasi dalam penerimaan peserta didik baru. Dalam sistem zonasi diatur bahwa sekolah yang diselenggarakan oleh pemerintah daerah wajib menerima calon peserta didik yang berdomisili pada radius zona terdekat dari sekolah, paling sedikit sebesar 90 persen dari total jumlah keseluruhan peserta didik yang diterima.

Penelitian ini bertujuan untuk menggambarkan persepsi masyarakat terhadap pelaksanaan kebijakan zonasi sekolah dalam PPDB tingkat SMA Tahun Ajaran 2017/2018 di Kota Samarinda. Jenis penelitian ini menggunakan penelitian kualitatif melalui metode penjelasan (explanatory). Teknik pengumpulan data dilakukan melalui wawancara dengan orang tua murid, perwakilan sekolah dan dinas terkait juga didukung oleh studi literatur yang berhubungan dengan kebijakan zonasi sekolah. Hasil penelitian menunjukkan bahwa pelaksanaan kebijakan zonasi sekolah menimbulkan gejolak di masyarakat. Waktu sosialisasi yang terbatas, kurangnya pemahaman terhadap mekanisme PPDB dengan sistem zonasi dan juga standar pendidikan yang masih belum merata merupakan beberapa kendala dalam pelaksanaannya di lapangan.
\end{abstract}

Kata Kunci : Persepsi, Kebijakan Zonasi Sekolah, SMA, Tahun Ajaran 2017/2018.

\begin{abstract}
Law Number 20 of 2003 concerning National Education System states that every citizen has the same right to obtain quality education. However, the phenomenon that occurs at this time, there is a gap that is quite visible because of the proliferation of superior labeled public schools initiated by the government in almost every region that opens a gap with other schools that are not superior. The flagship school seems to only be enjoyed by children with certain academic and financial abilities.
\end{abstract}


Parents also compete to send their children to this kind of schools. So the impact is that there are schools with many students and there are schools that lack students. Of course this inequality will lead to excesses that are not good in the world of national education.

In response to this, the government through the Ministry of Education and Culture set Permendikbud Number 17 of 2017 concerning New Student Admission (PPDB) in kindergartens, elementary schools, junior high schools, high schools, vocational high schools or other equivalent forms. In the Regulation of the Minister of Education and Culture, the zoning system was implemented in the acceptance of new students. In the zoning system it is regulated that schools organized by the local government must accept prospective students who are domiciled in the radius of the closest zone of the school, at least 90 percent of the total number of students received.

This study aims to describe public perception of the implementation on school zoning policy in the acceptance of new students at the high school year 2017/2018 in Samarinda. This type of research uses qualitative research through explanatory methods. Data collection techniques are carried out through interviews with parents, school and related agency representatives and also supported by literature studies related to school zoning policies. The results of the study show that the school zoning policy that was implemented starting in the year 2017/2018 caused turmoil in the community. Limited socialization time, lack of understanding of the PPDB mechanism with zoning systems and also education standards that are still not evenly distributed are some of the obstacles in its implementation in the field

Keywords: Perception, School Zoning Policy, High School, Year 2017/2018.

\section{PENDAHULUAN}

UU Nomor 20 Tahun 2003 tentang Sisdiknas dalam Pasal 5 ayat 1 menyebutkan bahwa setiap warga negara mempunyai hak yang sama untuk memperoleh pendidikan yang bermutu. Namun fenomena yang terjadi saat ini terdapat kesenjangan yang cukup kasat mata karena maraknya sekolah-sekolah negeri berlabel unggul yang digagas pemerintah di hampir setiap kabupaten/kota.

Marthunis (2017) menyebutkan bahwa sekolah unggulan disinyalir menjadi prioritas utama Dinas Pendidikan dan Kebudayaan dalam pemenuhan standar nasional pendidikan dan sudah menjadi rahasia umum bahwa sekolah unggul diperlakukan layaknya anak emas oleh dinas terkait.

Input sekolah yang berasal dari kalangan "eksklusif" membuat banyak privilege yang diberikan bagi sekolah unggulan, seperti pemenuhan sarana dan prasarana yang lengkap untuk menunjang proses pembelajaran, tenaga pengajar pilihan yang kompeten dan profesional, serta menjadi prioritas utama dalam pemberian akses untuk mengikuti berbagai perlombaan yang sifatnya regional, nasional, maupun internasional.

Hal ini tentu membuka jurang kesenjangan yang begitu lebar dengan sekolah-sekolah lain yang berstatus tidak unggul. Sekolah unggulan terkesan hanya bisa dinikmati anak-anak dengan kemampuan akademik serta finansial tertentu. Orang tua murid pun berlomba untuk menyekolahkan anaknya di sekolah unggulan. Sehingga dampaknya ada sekolah yang banyak muridnya dan ada sekolah yang kekurangan siswa. Tentu saja ketidakmerataan ini akan menimbulkan ekses yang tidak baik pada dunia pendidikan nasional.

Menyikapi hal tersebut, pemerintah melalui Kementerian Pendidikan dan Kebudayaan menetapkan Permendikbud Nomor 17 Tahun 2017 tentang Penerimaan Peserta Didik Baru (PPDB) pada Taman Kanak Kanak, Sekolah Dasar, Sekolah Menengah Pertama, Sekolah Menengah Atas, Sekolah Menengah Kejuruan atau bentuk Lain Yang Sederajat. Permendikbud tersebut mengatur tentang mekanisme pelaksanaan PPDB agar berjalan secara objektif, akuntabel, transparan dan tanpa diskriminasi sehingga mendorong peningkatan akses 
Persepsi Masyarakat Terhadap Implementasi Kebijakan Zonasi Sekolah Dalam Penerimaan Peserta Didik Baru (PPDB) Tingkat SMA Tahun Ajaran 2017/2018 Di Kota Samarinda

\section{Ratih Fenty A. Bintoro}

pendidikan. PPDB sendiri dilaksanakan melalui mekanisme dalam jejaring (daring/online) maupun dengan mekanisme luar jejaring (luring/offline). Persyaratan calon peserta didik diantaranya adalah menyangkut perihal kecukupan usia dan persyaratan administratif (khusus untuk calon peserta didik tingkat SMP dan SMA/SMK) terkecuali untuk peserta didik yang berkebutuhan khusus yang akan bersekolah di sekolah pendidikan inklusif. Selain persyaratan tersebut, Permendikbud 17 Tahun 2017 menetapkan syarat tambahan dalam proses seleksi calon peserta didik yaitu ketentuan zonasi. Dalam sistem zonasi diatur bahwa sekolah yang diselenggarakan oleh pemerintah daerah wajib menerima calon peserta didik yang berdomisili pada radius zona terdekat dari sekolah, paling sedikit sebesar 90 persen dari total jumlah keseluruhan peserta didik yang diterima.

Tabel 1. Syarat Seleksi Calon Peserta Didik Baru Tingkat SD, SMP dan SMA Berdasarkan Permendikbud 17 Tahun 2017

\begin{tabular}{lll}
\hline No & \multicolumn{1}{c}{$\begin{array}{c}\text { Tingkat } \\
\text { Pendidikan }\end{array}$} & \multicolumn{1}{c}{ Syarat Seleksi (berdasarkan urutan) } \\
\hline 1. & SD & 1. Usia \\
& & 2. Jarak tempat tinggal \\
2. SMP & 1. Jarak tempat tinggal \\
& & 2. Usia \\
& 3. Nilai Hasil Ujian SD \\
& 4. Prestasi Akademik dan Non Akademik \\
3. SMA & 1. Jarak tempat tinggal \\
& 2. Usia \\
& 3. Nilai Hasil Ujian SMP \\
& 4. Prestasi Akademik dan Non Akademik
\end{tabular}

Sumber : Permendikbud 17 Tahun 2017 (data diolah)

Penetapan kebijakan ini menuai banyak pro dan kontra di masyarakat. Beberapa daerah memprotes pemberlakukan kebijakan ini karena dianggap tidak sesuai dengan karakteristik daerah. Disdikbud Provinsi Kaltim sendiri melaksanakan secara penuh kebijakan ini dalam penerimaan peserta didik baru untuk tingkat SMA pada tahun ajaran 2017/2018. Berdasarkan Surat Keputusan Ketua MKKS SMA Kota Samarinda Tentang Zonasi Penerimaan Peserta Didik Baru (PPDB) Tahun Pelajaran 2017/2018, pembagian zonasi untuk tingkat SMA di Kota Samarinda terbagi menjadi 4 (empat) zona dengan perincian sebagai berikut :

Tabel 2. Zonasi Penerimaan Peserta Didik Baru (PPDB) Tahun Pelajaran 2017/2018

\begin{tabular}{|c|c|c|c|}
\hline No & Zona & Nama Sekolah & Kelurahan \\
\hline 1. & & SMAN 1 Samarinda & Air Hitam, Air Putih, Gunung Lingai, Bukit Pinang, \\
\hline 2. & I & SMAN 9 Samarinda & Sidodadi, Gunung Kelua, Sempaja Barat, Sempaja \\
\hline 3. & & SMAN 12 Samarinda & Timur, Sempaja Selatan, Sempaja Utara, \\
\hline 4. & & SMAN 13 Samarinda & $\begin{array}{l}\text { Mugirejo, Sungai Siring, Pampang, Tanah Merah, } \\
\text { Lempake. }\end{array}$ \\
\hline 5. & & SMAN 2 Samarinda & Sungai Kapih, Sambutan, Makroman, Sindang \\
\hline 6. & II & SMAN 11 Samarinda & Sari, Pulau Atas, Gunung Lingai, Selili, Sidomulyo, \\
\hline 7. & & SMAN 15 Samarinda & Sido Damai, Pelita, Karang Mumus, Pelabuhan, \\
\hline 8. & & SMAN 16 Samarinda & $\begin{array}{l}\text { Pinang Ular, Bandara, Sungai Pinang Dalam, } \\
\text { Temindung Permai, Dadi Mulya, Sungai Dama, } \\
\text { Mugirejo. }\end{array}$ \\
\hline
\end{tabular}




\begin{tabular}{|c|c|c|c|}
\hline 9. & & SMAN 3 Samarinda & Loa Buah, Loa Bakung, Loa Bahu, Karang Asam \\
\hline 10. & III & $\begin{array}{l}\text { SMAN } 5 \text { Samarinda } \\
\text { SMAN } 8 \text { Samarinda }\end{array}$ & $\begin{array}{l}\text { Ulu, Air Putih, Teluk Lerong Ulu, Teluk Lerong Ilir, } \\
\text { Karang Anyar, Kampung Jawa, Bukit Pinang, Pasar }\end{array}$ \\
\hline 12. & & SMAN 14 Samarinda & Pagi, Kampung Bugis, Loa Kumbar. \\
\hline $\begin{array}{l}13 . \\
14 . \\
15 . \\
16 .\end{array}$ & IV & $\begin{array}{l}\text { SMAN } 4 \text { Samarinda } \\
\text { SMAN } 6 \text { Samarinda } \\
\text { SMAN } 7 \text { Samarinda } \\
\text { SMAN } 17 \text { Samarinda }\end{array}$ & $\begin{array}{l}\text { Simpang Pasir, Handil Bakti, Rawa Makmur, } \\
\text { Bukuan, Batuah, Harapan Baru, Rapak Dalam, } \\
\text { Sengkotek, Simpang Tiga, Tani Aman, Sungai } \\
\text { Keledang, Baqa, Masjid, Mangkupalas, Tenun, } \\
\text { Gunung Panjang. }\end{array}$ \\
\hline
\end{tabular}

Sumber : MKKS SMA Kota Samarinda (2017)

Penentuan zona ditetapkan oleh Disdikbud Prov. Kaltim dengan melibatkan musyawarah/kelompok kerja kepala sekolah dan disesuaikan dengan kondisi daerah dengan memperhatikan ketersediaan anak usia sekolah dan jumlah ketersediaan daya tampung sekolah.

Sebagai tahun awal pelaksanaan kebijakan tentu banyak gejolak dan adaptasi yang harus dilakukan, maka dari itu menarik untuk melihat persepsi masyarakat terhadap pelaksanaan kebijakan zonasi sekolah khususnya dalam penerimaan peserta didik baru tingkat SMA di Kota Samarinda. Thoha (1983) menjelaskan persepsi timbul karena adanya dua faktor yaitu internal dan eksternal. Faktor internal bergantung pada proses pemahaman sesuatu termasuk didalamnya sistem nilai, tujuan, kepercayaan dan tanggapannya terhadap hasil yang dicapai. Faktor eksternal meliputi faktor lingkungan, faktor konsepsi, faktor motif/ujuan dan faktor pengalaman di masa lampau.

\section{METODE}

Penelitian ini menggunakan metode penelitian penjelasan (explanatory). Penelitian ini dapat dinilai sesuai dengan tingkat yang didasarkan pada tujuan dan objek yaitu yang bertujuan untuk mempelajari, menjelaskan, mendeteksi, dan beberapa sisanya menyelidiki kausalitas (Tantri dkk, 2011). Teknik pengambilan sampel yang digunakan adalah metode snowball sampling. Sampel dalam penelitian ini adalah Dinas Pendidikan Prov. Kaltim, Perwakilan Sekolah (Kepala Sekolah dan Guru) dan Masyarakat (Orang Tua Murid).

Penelitian dilakukan selama 3 bulan dari bulan Januari-Maret 2018 dengan memfokuskan pada PPDB tingkat SMA di Kota Samarinda untuk Tahun Ajaran 2017-2018 berdasarkan Permendikbud Nomor 17 Tahun 2017 tentang Penerimaan Peserta Didik Baru pada Taman Kanak Kanak, Sekolah Dasar, Sekolah Menengah Pertama, Sekolah Menengah Atas, Sekolah Menengah Kejuruan atau bentuk Lain yang sederajat.

\section{HASIL DAN PEMBAHASAN}

Pendidikan yang bermutu merupakan hak semua orang. Semua anak Indonesia mempunyai hak yang sama untuk mendapatkan pendidikan yang berkualitas dan berhak menjadi yang terbaik, terlepas apakah dia dari golongan kaya atau pun miskin. Dalam rangka mempercepat terwujudnya pemerataan pendidikan yang berkualitas, Kementerian Pendidikan dan Kebudayaan terus berupaya menciptakan program program prioritas salah satunya dengan memberlakukan sistem zonasi pada penerimaan peserta didik baru sebagaimana diatur dalam Permendikbud Nomor 17 Tahun 2017. Sistem zonasi ini merupakan sistem yang mengharuskan sekolah untuk menerima semua calon peserta didik yang mendaftar sesuai zonasinya tanpa terkecuali. Dengan demikian, diharapkan akan mengurangi eksklusifitas, rivalitas serta 
Persepsi Masyarakat Terhadap Implementasi Kebijakan Zonasi Sekolah Dalam Penerimaan Peserta Didik Baru (PPDB) Tingkat SMA Tahun Ajaran 2017/2018 Di Kota Samarinda

\section{Ratih Fenty A. Bintoro}

diskriminasi di sekolah sekolah negeri yang merupakan barang publik (public goods). Tidak ada lagi sekolah favorit dan tidak favorit. Dengan sistem zonasi sekolah maka yang dipakai bukan lagi lokasi sekolah atas dasar pemerintahan tetapi seberapa jauh tempat tinggal siswa dengan sekolah. Diharapkan biaya akomodasi siswa untuk menuju sekolah dapat lebih kecil. Sistem zonasi sekolah juga dapat membuat peserta didik yang pintar bisa menyebar di sekolah sekolah. Dengan demikian siswa pintar bisa membantu siswa yang kesulitan dalam belajar.

Dalam pelaksanaannya dalam PPDB Tahun Pelajaran 2017/2018, Dinas Pendidikan Prov. Kaltim kemudian mengeluarkan Keputusan Kepala Dinas Pendidikan dan Kebudayaan Prov. Kaltim Nomor 421/6890/Disdikbud.III/2017 tentang Petunjuk Teknis Penerimaan Peserta Didik Baru (PPDB) Tahun Pelajaran 2017/2018 dimana dalam pasal 16 Juknis tersebut dijelaskan tentang ketentuan sistem zonasi sebagai berikut :

1. Sekolah yang diselenggarakan oleh pemerintah daerah wajib menerima calon peserta didik yang berdomisili pada zona yang ditentukan paling sedikit sebesar $90 \%$ dari total jumlah keseluruhan peserta didik yang diterima;

2. Domisili calon peserta didik sebagaimana dimaksud pada ayat (1) berdasarkan alamat pada kartu keluarga yang diterbitkan paling lambat 6 (enam) bulan sebelum pelaksanaan PPDB;

3. Zona sebagaimana dimaksud pada ayat (1) ditetapkan oleh pemerintah daerah sesuai dengan kondisi di daerah tersebut berdasarkan jumlah ketersediaan daya tampung berdasarkan ketentuan rombongan belajar masing masing sekolah dengan ketersediaan anak usia sekolah di daerah tersebut;

4. Bagi sekolah yang berada di daerah perbatasan provinsi atau kabupaten/kota, ketentuan persentase dan zona sebagaimana dimaksud pada ayat (1) dapat diterapkan melalui kesepakatan secara tertulis antar pemerintah daerah yang saling berbatasan;

5. Sekolah yang diselenggarakan oleh pemerintah daerah dapat menerima calon peserta didik melalui :

a. Jalur luar daerah (Kab/Kota) dan Provinsi paling banyak $2 \%$;

b. Jalur bagi calon peserta didik yang berdomisili di luar zona terdekat dari sekolah dengan alasan khusus meliputi perpindahan domisili orangtua/wali peserta didik atau terjadi bencana alam/social, paling banyak $3 \%$ dari total jumlah keselurihan peserta didik yang diterima;

c. Jalur prestasi yang berdomisili di luar zona dari sekolah paling banyak $5 \%$ dari total jumlah keseluruhan peserta didik yang diterima;

d. Yang dimaksud jalur luar daerah sebagaimana disebut pada huruf a adalah calon peserta didik yang berdomisili di luar Kabupaten/Kota sekolah pilihan;

e. Yang dimaksud jalur prestasi sebagaimana disebut pada huruf c adalah prestasi akademik dan/atau non akademik yang dilaksanakan secara berjenjang dengan menunjukkan bukti berupa Surat Keputusan dan sertifikat kejuaraan dari tingkat Kabupaten/Kota sampai internasional yang diselenggarakan oleh Dinas Pendidikan dan Kebudayaan, Kementerian Pendidikan dan Kebudayaan (OSN, O2SN dan FLS2N).

Ketentuan sistem zonasi dalam juknis ini sedikit berbeda dengan ketentuan dalam Permendikbud 17 Tahun 2017, dimana dalam juknis terdapat penambahan jalur penerimaan yaitu jalur luar daerah (Kab/Kota) dan Provinsi paling banyak $2 \%$ (poin a) dan juga penurunan persentase dari $5 \%$ menjadi $2 \%$ untuk jalur bagi calon peserta didik yang berdomisili di luar zona terdekat dari sekolah dengan alasan khusus meliputi perpindahan domisili orangtua/wali peserta didik atau terjadi bencana alam/sosial (poin b). Penyesuaian ini dilakukan dengan memperhatikan kondisi di Kaltim (daya tampung sekolah dan ketersedian anak usia sekolah). 
Dari hasil wawancara dengan Dinas Pendidikan, tenaga pendidik maupun orang tua murid terkait penerapan system zonasi sekolah pada tahun 2017/2018 didapatkan hasil sebagai berikut:

\section{Adanya Kekhawatiran Akan Tertutupnya Kemungkinan Untuk Bersekolah Di Luar Zonasi.}

Sebelum diterapkannya sistem zonasi, seleksi PPDB dilakukan dengan menggunakan nilai tertinggi yang berasal dari nilai evaluasi belajar murni (NEM). Hal ini mengakibatkan munculnya istilah sekolah favorit. Istilah inilah yang membuat para siswa baru berlomba lomba untuk dapat masuk di sekolah yang dicap favorit. Ditetapkannya kebijakan zonasi menimbulkan kekhawatiran terutama bagi calon peserta didik dan juga wali murid yang merasa adanya pembatasan dalam memilih sekolah yang diinginkan, mereka tidak dapat masuk ke sekolah yang menjadi incaran namun berbeda zonasi tempat tinggal, apalagi secara aturan kuota untuk calon peserta didik yang berdomisili pada radius terdekat dari sekolah ditetapkan cukup besar sebanyak $90 \%$

Namun kekhawatiran ini dinilai tidak beralasan karena pada dasarnya ketentuan zonasi ini tidak lantas menutup peluang murid untuk bersekolah di sekolah yang diinginkannya hanya karena berbeda zonasi, masih tetap terbuka peluang untuk mendaftar di jalur lintas zona ataupun jalur prestasi dan juga implementasi peraturan tersebut tetap disesuaikan dengan kondisi lokal pendidikan di Kaltim sebagaimana disampaikan oleh Kepala Disdikbud Prov. Kaltim, dikutip dari kaltimprokal.co :

"Itu tetap bisa. Kan ada jalur lintas zona serta jalur prestasi. Jadi begini, Disdik hanya meneruskan apa yang diatur oleh Mendikbud. Tetapi, dalam implementasi aturan Mendikbud tersebut, kami juga memperhitungkan kondisi lokal pendidikan di Kaltim. Kami tak harga mati. Jadi, jangan sampai, ada pikiran, mau sekolah kayaknya sulit. Jalur lintas zonasi itu, misalnya, ada siswa yang tinggal, di Simpang Pasir Palaran (zona IV), tetapi ingin melamar di SMA 1 (zona I), maka itu bisa dilakukan, dengan jalur prestasi dan lintas zona".

Hal tersebut ditegaskan kembali oleh Abdul Rozak, Kepala SMAN 3 Samarinda sekaligus Ketua MKKS Swasta :

"Kalau ingin masuk lintas zona, itu diperbolehkan tanpa prestasi. Tetapi nilai ujiannya harus tinggi. Selain itu, kuotanya hanya 3 persen. Jadi, tanpa punya sertifikat prestasi, juga bisa mendaftar di sekolah yang diluar zonasinya. Yang penting, dia mau, berani, karena kuotanya hanya 3 persen. Kuota 3 persen ini sama untuk se-Samarinda, karena sesuai dengan arahan Didik,"

Sesuai Juknis PPDB Tahun Ajaran 2017/2018 pasal 16 ayat 5 disebutkan bahwa diluar ketentuan zonasi $90 \%$, sekolah yang diselenggarakan oleh pemerintah daerah dapat menerima calon peserta didik melalui :

a. Jalur luar daerah (Kab/Kota) dan Provinsi paling banyak $2 \%$;

b. Jalur bagi calon peserta didik yang berdomisili di luar zona terdekat dari sekolah dengan alasan khusus meliputi perpindahan domisili orangtua/wali peserta didik atau terjadi bencana alam/social, paling banyak $3 \%$ dari total jumlah keselurihan peserta didik yang diterima;

c. Jalur prestasi yang berdomisili di luar zona dari sekolah paling banyak $5 \%$ dari total jumlah keseluruhan peserta didik yang diterima;

Aturan ini memberikan peluang bagi calon peserta didik untuk tetap bersekolah di luar zonasinya dengan pertimbangan pertimbangan tertentu. 
Persepsi Masyarakat Terhadap Implementasi Kebijakan Zonasi Sekolah Dalam Penerimaan Peserta Didik Baru (PPDB) Tingkat SMA Tahun Ajaran 2017/2018 Di Kota Samarinda

Ratih Fenty A. Bintoro

\section{Kurangnya Sosialisasi Kebijakan Zonasi}

Aturan mengenai kebijakan zonasi sekolah ditetapkan melalui Permendikbud Nomor 17 Tahun 2017 pada bulan Mei 2017, untuk kemudian dilaksanakan pada bulan Juni 2017. Singkatnya waktu tersebut menimbulkan gejolak di masyarakat. Tidak semua masyarakat paham mengenai tujuan dan aturan pelaksanaan kebijakan zonasi sekolah tersebut sehingga menimbulkan kebingungan sebagaimana disampaikan oleh Bapak Kirdon yang merupakan salah satu orang tua murid yang mendaftarkan anaknya di salah satu SMA pada PPDB Tahun Ajaran 2017/2018 dalam wawancara sebagai berikut :

"Jadi kemarin kita sempat bingung, bertanya tanya langsung ke sekolahan, dari situ ada penjelasan dari petugas sekolahan. Dapat informasi tanggal sekian sampai sekian itu pendaftaran zonasi lingkungan sekolahan. Lingkungan sekolah itu dari batas RT sekian ke sekian, pokoknya lingkungan sekolah. Setelah itu ada waktunya 2 (dua) hari kemudian zona umum yang masuk per kecamatan, atau per kelurahan dari situ kita ikut. Nah dari situ kita bisa pilih, kita daftar satu sekolahan, pertama itu sekolah yang dituju, kalau memang ngak masuk, ada pilihan kedua dan ketiga. Pilihan dua dan tiga itu kalau kita sudah lepas dari kuota sekolah pilihan yang pertama. Dilihat kuota sekolah, kalau nilainya masuk, kuotanya cukup, kita tinggal tunggu saja”

Hal senada disampaikan oleh orang tua murid lainnya, Bapak Sulaiman dalam wawancara berikut :

"Sosialisasinya pada saat itu, pada saat pelaksanaan pendaftaran, ada pengumuman yang ditempel tentang tata tertib penerimaan. Alhamdulillah (waktu) penerimaannya agak panjang. Dibagi per kriteria. Ada memang beberapa ortu murid yang protes, bertanya tanya tapi sedikit aja."

Dari wawancara diatas dapat disimpulkan bahwa mengingat keterbatasan waktu maka sosialisasi kebijakan zonasi dilaksanakan pada saat pelaksanaan pendaftaran. Peran petugas sekolah sangat penting dalam memberikan pemahaman kepada masyarakat perihal kebijakan zonasi yang baru ditetapkan pertama kali pada tahun ajaran 2017/2018 tersebut. Beberapa sekolah sendiri sudah menginisiasi sosialisasi dengan memasang spanduk dan pengumuman di website sekolah masing masing.

Permasalahan waktu sosialisasi yang terbatas dan pada akhirnya membingungkan orang tua atau wali murid ini juga senada dengan hasil penelitian yang dilakukan oleh Hermin Aprilia Susanti (2017) dalam penelitiannya yang berjudul Implementasi Kebijakan Penerimaan Peserta Didik Baru (PPDB) di SMA Negeri 4 Kota Madiun Tahun 2017. Hermin Aprilia Susanti meneliti tentang mekanisme pelaksanaan PPDB dengan menggunakan teori Van Metter dan Horn. Dalam temuannya berkaitan dengan sistem zonasi, dilihat dari segi sosial dan politik, kebijakan sistem zonasi ini dirasa terburu buru sehingga membingungkan orang tua atau wali murid. Selain itu juga membuat orang tua atau wali murid seperti tidak siap untuk menerima kebijakan zonasi tersebut.

\section{Adanya Kekhawatiran Perihal Standar Pendidikan Yang Tidak Merata.}

Pemberlakukan kebijakan zonasi bertujuan untuk pemerataan pendidikan yang berkualitas, namun terdapat beberapa kekhawatiran mengenai tepat atau tidaknya kebijakan ini diterapkan di daerah khususnya di Kota Samarinda, karena bila ditelusuri masih banyak standar nasional pendidikan yang masih belum memenuhi standar. Hal ini sebagaimana dijelaskan oleh salah satu Kepala Sekolah di Kota Samarinda ketika dimintai pendapat mengenai kesesuaian pelaksanaan kebijakan zonasi diterapkan di Kota Samarinda sebagai berikut : 
“..Jadi gambaran, antar pendapat pak menteri dengan Permendikbud, tidak bisa disamaratakan seluruh Indonesia, kalau di Jakarta ada 200 sekolah misalkan, ada SMA 70, ini SMA favorit yang masuk di zona itu tanpa ribet dia pasti mau masuk sekolah itu. Kita ambil gambaran di Samarinda, SMA 14 di Loa Bakung, apakah mungkin masyarakat di Korpri itu mau masuk SMA 14? Yang sekolahnya masih numpang, masuk sore?nah ini, ini harusnya sistem zonasi ini, kalau pemerintah mau sistem zonasi ini, distandarkan dulu semua sekolah, pertama standar mutu guru, sarana prasarana. Begitu standar sapras dan guru sudah cukup, maka masyarakat di sekitarnya disuruh sekolah di sekolah tersebut pasti tidak menolak. Kalau di Jakarta, dari SMA 1 sampai SMA 200 (misalnya) di Jakarta,itu standarnya sudah sama, walaupun naik turun, tapi standarnya sudah terpenuhi. Itu yang terus saya pikirkan, kok mudah betul diterapkan di daerah.padahal tidak semua sama parameternya seperti di Jakarta “

Pemerintah sebagai penyelenggara urusan pendidikan dalam melaksanakan urusan pendidikan berpedoman pada Standar Nasional Pendidikan yang merupakan kriteria minimal tentang sistem pendidikan di seluruh wilayah hukum Negara Kesatuan Republik Indoneisa. Standar Nasional Pendidikan itu sendiri terdiri dari 8 poin yang harus dimiliki dan dipenuhi oleh penyelenggara dan/atau satuan pendidikan yang ada di Indonesia yaitu :

1. Standar Kompetensi Lulusan.

2. Standar Isi

3. Standar Proses.

4. Standar Penilaian Pendidikan.

5. Standar Pendidikan dan Tenaga Kependidikan.

6. Standar Sarana dan Prasarana.

7. Standar Pengelolaan.

8. Standar Pembiayaan Pendidikan.

Dari laporan analisis mutu pendidikan tahun 2017 yang dikeluarkan oleh Lembaga Penjamin Mutu Pendidikan Prov. Kaltim, dapat dilihat bahwa capaian 8 standar nasional pendidikan Provinsi Kaltim jenjang SMA seluruhnya masih belum memenuhi standar nasional pendidikan. Capaiannya masih berkisar pada tahap 3 atau tahap 4. Lebih lengkapnya dapat dilihat dalam tabel berikut :

Tabel 3. Capaian 8 SNP Provinsi Kaltim Jenjang SMA Tahun 2017

\begin{tabular}{clll}
\hline No & \multicolumn{1}{c}{ SNP } & Capaian & Kategori \\
\hline 1. & Standar Kompetensi Lulusan. & 0.84667 & Belum SNP = Tahap 4 \\
2. & Standar Isi & 0.90012 & Belum SNP = Tahap 4 \\
3. & Standar Proses. & 0.85202 & Belum SNP = Tahap 4 \\
4. & Standar Penilaian Pendidikan. & 0.93303 & Belum SNP = Tahap 4 \\
5. & Standar Pendidikan dan Tenaga Kependidikan. & 0.73199 & Belum SNP = Tahap 3 \\
6. & Standar Sarana dan Prasarana. & 0.70557 & Belum SNP = Tahap 3 \\
7. & Standar Pengelolaan. & 0.91414 & Belum SNP = Tahap 4 \\
8. & Standar Pembiayaan Pendidikan. & 0.76303 & Belum SNP $=$ Tahap 4 \\
\hline
\end{tabular}

Sumber : LPMP Kaltim, 2017

Tabel 4. Kategorisasi Hasil Capaian 8 SNP

\begin{tabular}{lll}
\hline No & Capaian & Kategori \\
\hline
\end{tabular}


Persepsi Masyarakat Terhadap Implementasi Kebijakan Zonasi Sekolah Dalam Penerimaan Peserta Didik Baru (PPDB) Tingkat SMA Tahun Ajaran 2017/2018 Di Kota Samarinda

Ratih Fenty A. Bintoro

\begin{tabular}{clc}
\hline 1. & $0.000-0.2499$ & Belum SNP = Tahap 1 \\
2. & $0.250-0.499$ & Belum SNP = Tahap 2 \\
3. & $0.500-0.7499$ & Belum SNP = Tahap 3 \\
4. & $0.750-0.999$ & Belum SNP = Tahap 4 \\
5. & 1 & SNP \\
\hline Sumber $:$ LPMP Kaltim, 2017 &
\end{tabular}

Dari tabel 3 dapat dilihat bahwa standar nasional pendidikan yang masih berada dalam tahap 3 adalah standar sarana prasarana dan standar pendidikan dan tenaga kependidikan. Khusus Kota Samarinda, sarana dan prasarana pendidikan di Kota Samarinda dinilai masih belum merata, masih banyak sekolah yang belum memiliki gedung sekolah sendiri dan tidak dalam kondisi baik. Untuk tingkat SMA, tercatat saat ini masih ada tiga sekolah yang masih menumpang dengan sekolah lain yakni SMA 14, SMA 16 dan SMA 17 (data per September 2017). Alasannya pun bervariasi, khusus SMA 14, dulunya Pemkot Samarinda sudah membangunkan gedung. Namun belakangan muncul kebijakan pemerintah pusat yang menarik SMA menjadi tanggung jawab provinsi. Akibatnya gedung yang diperuntukan bagi SMA 14 kini diperuntukan bagi SMP 038 yang juga masih menumpang di SD 027 Loa Bakung. Jumlah murid yang masih di bawah standar seperti yang dialami SMA 17 juga menjadi alasan mengapa belum diadakan pembangunan gedung mandiri.

Selain ketersediaan gedung sekolah, kondisi ruang kelas juga patut menjadi perhatian. Dari data Neraca Pendidikan Daerah Kementerian Pendidikan dan Kebudayaan Tahun 2016, kondisi ruang kelas SMA di Kota Samarinda tercatat 258 ruang kelas dalam kondisi baik, dan 150 ruang kelas dalam kondisi rusak ringan.

Pemenuhan standar pendidikan menjadi hal yang mendesak dirasakan untuk dipenuhi sehingga masyarakat dapat menyambut baik kebijakan zonasi, sebagaimana disampaikan oleh salah seorang Guru SMA di Kota Samarinda sebagai berikut :

"Kalau mau bantu masyarakat, sistem zona ini harus dipenuhi dahulu, kalau memang mau standarkan, kalau bisa 8 standar yang dilengkapi. Kalau ngak bisa ya sapras dan guru yang distandarkan terlebih dahulu......"

\section{KESIMPULAN}

Tahun ajaran 2017/2018 menjadi tahun awal diterapkannya sistem zonasi secara nasional dalam penerimaan peserta didik baru. Sebagai tahun transisi, ditemukan banyak gejolak di masyarakat terkait kebijakan ini. Waktu sosialisasi yang terbatas yang pada akhirnya berpengaruh pada pemahaman masyarakat akan mekanisme baru dalam penerimaan peserta didik baru pasca ditetapkannya kebijakan zonasi melalui Permendikbud 17 Tahun 2017 tersebut. Selain itu, standar pendidikan yang belum merata di semua sekolah juga turut menjadi kekhawatiran akan kesiapan daerah dalam melaksanakan kebijakan zonasi.

\section{REKOMENDASI}

Tujuan mulia kebijakan zonasi adalah adanya pemerataan pendidikan, namun terdapat beberapa hal yang perlu menjadi perhatian untuk perbaikan pelaksanaan kebijakan zonasi bila akan diterapkan kembali pada tahun ajaran tahun berikutnya.

1. Perlu adanya sosialisasi yang masif dan waktu sosialisasi yang panjang terkait sistem zonasi PPDB sehingga Dinas Pendidikan dan masyarakat memahami kebijakan PPDB. 
2. Pemerintah pusat dan pemerintah daerah harus segera memenuhi standar nasional pendidikan yang merata.

\section{UCAPAN TERIMAKASIH}

Ucapan terima kasih disampaikan kepada informan dalam penelitian ini yang telah meluangkan waktunya untuk memberikan informasi mengenai pelaksanaan kebijakan zonasi di tingkat SMA pada tahun ajaran 2017/2018. Semoga hasil penelitian ini dapat menjadi masukan dan gambaran mengenai kendala yang terjadi di lapangan sehingga terdapat perbaikan untuk pelaksanaan di tahun tahun berikutnya.

\section{DAFTAR PUSTAKA}

Hermin Aprilia, Lestari. (2018). Implementasi Kebijakan Penerimaan Peserta Didik Baru $(P P D B)$ di SMA Negeri 4 Kota Madiun Tahun 2017. Ilmu Administrasi Negara Universitas Negeri Surabaya.

LPMP Kaltim. (2018). Analisis Peta Mutu Pendidikan Provinsi Kalimantan Timur Tahun 2017. Samarinda

Marthunis, (2017). Sekolah Unggulan, Disparitas Dalam Pendidikan. Dari http://mediaindonesia.com/newa/read/88786/sekolah-unggulan-disparitas-dalampendidikan/2017-01-23, diakses pada 29 Januari 2018.

Pemerintah Provinsi Kalimantan Timur. (2017). Keputusan Kepala Dinas Pendidikan dan Kebudayaan Prov. Kaltim Nomor 421/6890/Disdikbud.III/2017 tentang Petunjuk Teknis Penerimaan Peserta Didik Baru (PPDB) Tahun Pelajaran 2017/2018.

Republik Indonesia. (2017). Permendikbud Nomor 17 Tahun 2017 tentang Penerimaan Peserta Didik Baru pada Taman Kanak Kanak, Sekolah Dasar, Sekolah Menengah Pertama, Sekolah Menengah Atas, Sekolah Menengah Kejuruan atau bentuk Lain yang sederajat.

Tantri dkk. (2011). Analisa Gender, Gaya Kepemimpinan dan Budaya Organisasi Terhadap Produktivitas Sekolah Dasar Negara di Kabupaten Sidoarjo. Jurnal Aplikasi Manajemen. Volme 9 No. 3.

Thoha, Miftah. (1983). Perilaku Organisasi. Jakarta : Rajawali Press. 